\title{
STRATIGRAPHIC CORRELATION OF LATE WEICHSELIAN AND HOLOCENE DEPOSITS IN THE LITHUANIAN COASTAL REGION
}

\author{
Albertas BITINAS ${ }^{\mathrm{a}}$, Aldona DAMUŠYTÉ ${ }^{\mathrm{a}}$, Galina HÜTT ${ }^{\mathrm{b}}$, Tõnu MARTMA ${ }^{\mathrm{b}}$,

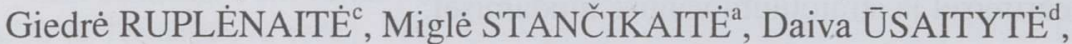 \\ and Rein VAIKMÄE
}

${ }^{a}$ Geological Survey of Lithuania, S. Konarskio 35, LT-2600 Vilnius, Lithuania

${ }^{b}$ Institute of Geology, Tallinn Technical University, Estonia pst. 7, 10143 Tallinn, Estonia

c Institute of Geography, Akademijos 2, LT-2600 Vilnius, Lithuania

d Department of Geology and Mineralogy, Vilnius University, Čiurlionio 21/27, LT-2009 Vilnius, Lithuania (Present address: Institute of Earth Sciences, Uppsala University, Villavägen 16, S-75236 Uppsala, Sweden)

Received 29 February 2000, in revised form 27 April 2000

\begin{abstract}
The Lithuanian coastal region serves as a key area for solving different problems of Quaternary geology, particularly those related to the development of the Baltic Sea in Late Weichselian and Holocene times. Within this research, Late Weichselian and Holocene deposits in three localities in the northern part of the Lithuanian coastal region were studied. The set of methods used included palynological and diatom analysis, palaeontological investigation of subfossil mollusc fauna, measurements of the isotopic composition $\left(\delta^{13} \mathrm{C}\right.$ and $\left.\delta^{18} \mathrm{O}\right)$ of mollusc shells, radiocarbon dating of molluscs and organic deposits, and optically stimulated luminescence (OSL) dating of sandy deposits. The studies showed that the coastal deposits in the northern part of the Lithuanian coastal region formed during the Baltic Ice Lake, Ancylus Lake, Litorina Sea, and Post-Litorina Sea stages of the Baltic Sea evolution. The OSL technique, which was used for the first time in dating relatively young marine sandy deposits in Lithuania, yielded the results fitting in with palaeobotanical, palaeontological, and radiocarbon data, particularly in the case of deposits younger than 5000 years.
\end{abstract}

Key words: Baltic Sea, Late Weichselian, Holocene, luminescence, isotopes, radiocarbon, palynology.

\section{INTRODUCTION}

The Lithuanian coastal region extends for about $100 \mathrm{~km}$ along the southeast coast of the Baltic Sea, including also the northern part of the semiclosed freshwater lagoon Kuršiu Marios (Fig. 1). From the geological point of view, this 
region serves as a key area for solving different problems related to the evolution of the Baltic Sea in the Quaternary, particularly during the Late Weichselian and Holocene, since lacustrine and marine deposits of these periods are widespread in the Lithuanian coastal zone. Detailed research into the geological sections and their correlation with similar sections elsewhere in the Baltic Sea and on its coasts are an important prerequisite to elucidating the Late Weichselian and Holocene history of the Baltic Sea.

The research in the Lithuanian coastal zone and the Kuršių Nerija Spit was initiated in the second half of the 19th century; the first papers were published by the German scientists G. Berendt and J. Schumann in 1869. The Kuršių Nerija Spit was investigated at the beginning of the 20th century as well. The most significant studies were published by H. von Wichdorff in 1917 and O. Pratje in 1931 (Kabailiene 1990). However, it was not until the end of the Second World War that the foundation was laid for systematic geological, geomorphological,

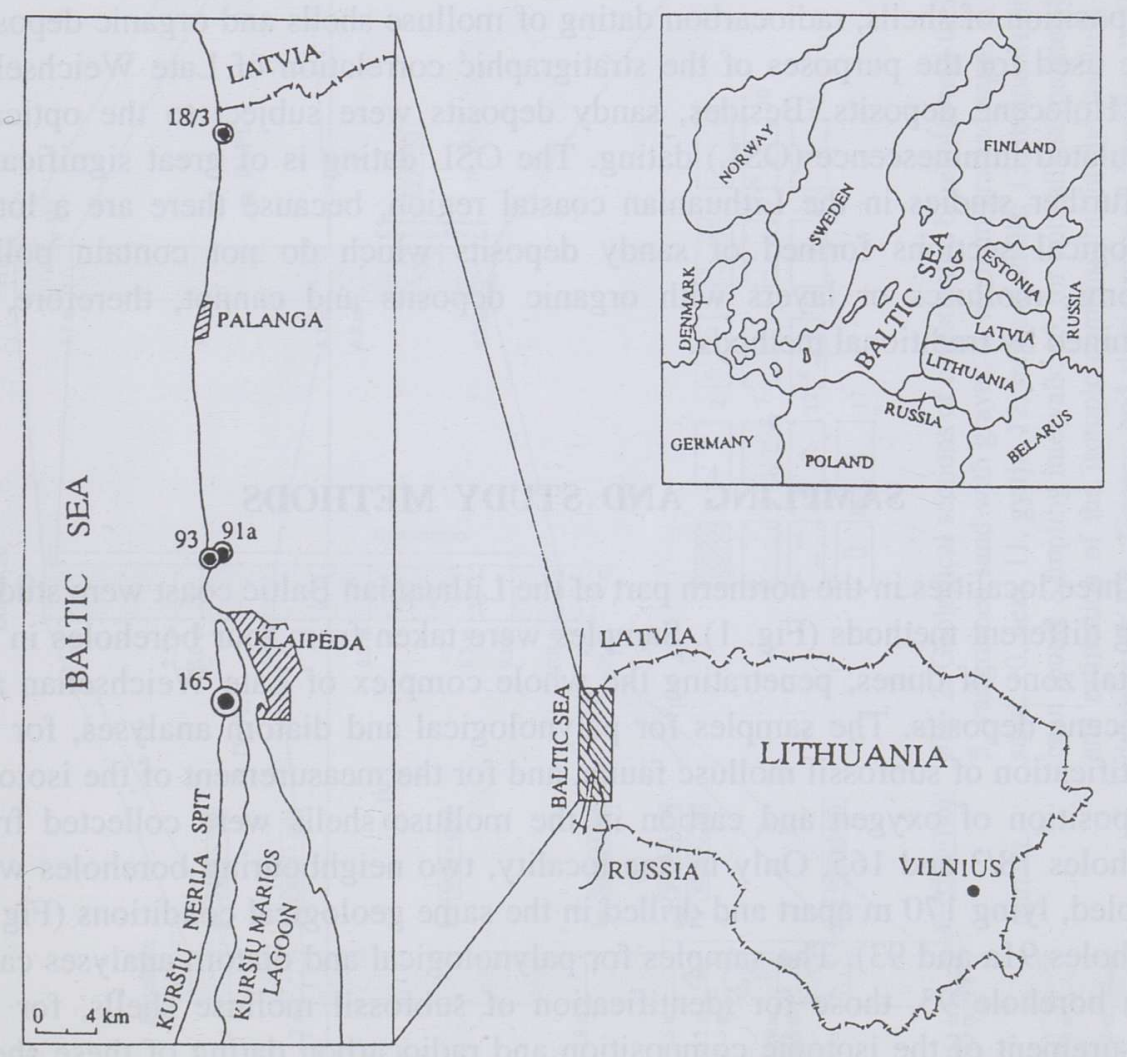

Fig. 1. Location of investigated boreholes. 
and palaeobotanical investigations. The geological mapping of the Lithuanian coastal zone at a scale of $1: 200000$ was carried out in 1960, and of the Baltic Sea floor in 1987. The 1:50000 scale geological maps of the northern parts of the Lithuanian offshore and onshore areas were completed in 1997 and 1998, respectively. Different investigations into stratigraphy, palaeogeography, lithology, etc. have been conducted in the post-war period as well (e.g. Gudelis 1955, 1979; Gudelis \& Klimavičienè 1982; Mikalauskas et al. 1986; Mikalauskas \& Lukoševičius 1987).

However, despite much research, many topical problems connected with the Baltic Sea history are unsolved as yet. Disagreements arise for a variety of reasons, one of those being the insufficient study of geological sections with Late Weichselian and Holocene deposits. This paper presents the results of the first detailed complex examination of the Late Weichselian and Holocene deposits in the northern part of the Lithuanian coastal region. Traditional research methods, including the palynological and diatom analysis, palaeontological investigations of subfossil mollusc fauna together with the measurement of the isotopic composition of shells, radiocarbon dating of mollusc shells and organic deposits, were used for the purposes of the stratigraphic correlation of Late Weichselian and Holocene deposits. Besides, sandy deposits were subject to the optically stimulated luminescence (OSL) dating. The OSL dating is of great significance for further studies in the Lithuanian coastal region, because there are a lot of geological sections formed of sandy deposits which do not contain pollen, diatoms, molluscs or layers with organic deposits and cannot, therefore, be examined by traditional methods.

\section{SAMPLING AND STUDY METHODS}

Three localities in the northern part of the Lithuanian Baltic coast were studied using different methods (Fig. 1). Samples were taken from four boreholes in the coastal zone of dunes, penetrating the whole complex of Late Weichselian and Holocene deposits. The samples for palynological and diatom analyses, for the identification of subfossil mollusc fauna, and for the measurement of the isotopic composition of oxygen and carbon in the mollusc shells were collected from boreholes $18 / 3$ and 165 . Only in one locality, two neighbouring boreholes were sampled, lying $170 \mathrm{~m}$ apart and drilled in the same geological conditions (Fig. 2, boreholes 91a and 93). The samples for palynological and diatom analyses came from borehole 93, those for identification of subfossil mollusc shells, for the measurement of the isotopic composition and radiocarbon dating of these shells from the neighbouring borehole $91 \mathrm{a}$, which is much richer in the mollusc fauna. The samples for the OSL dating were taken from boreholes $18 / 3$ and 165 . 


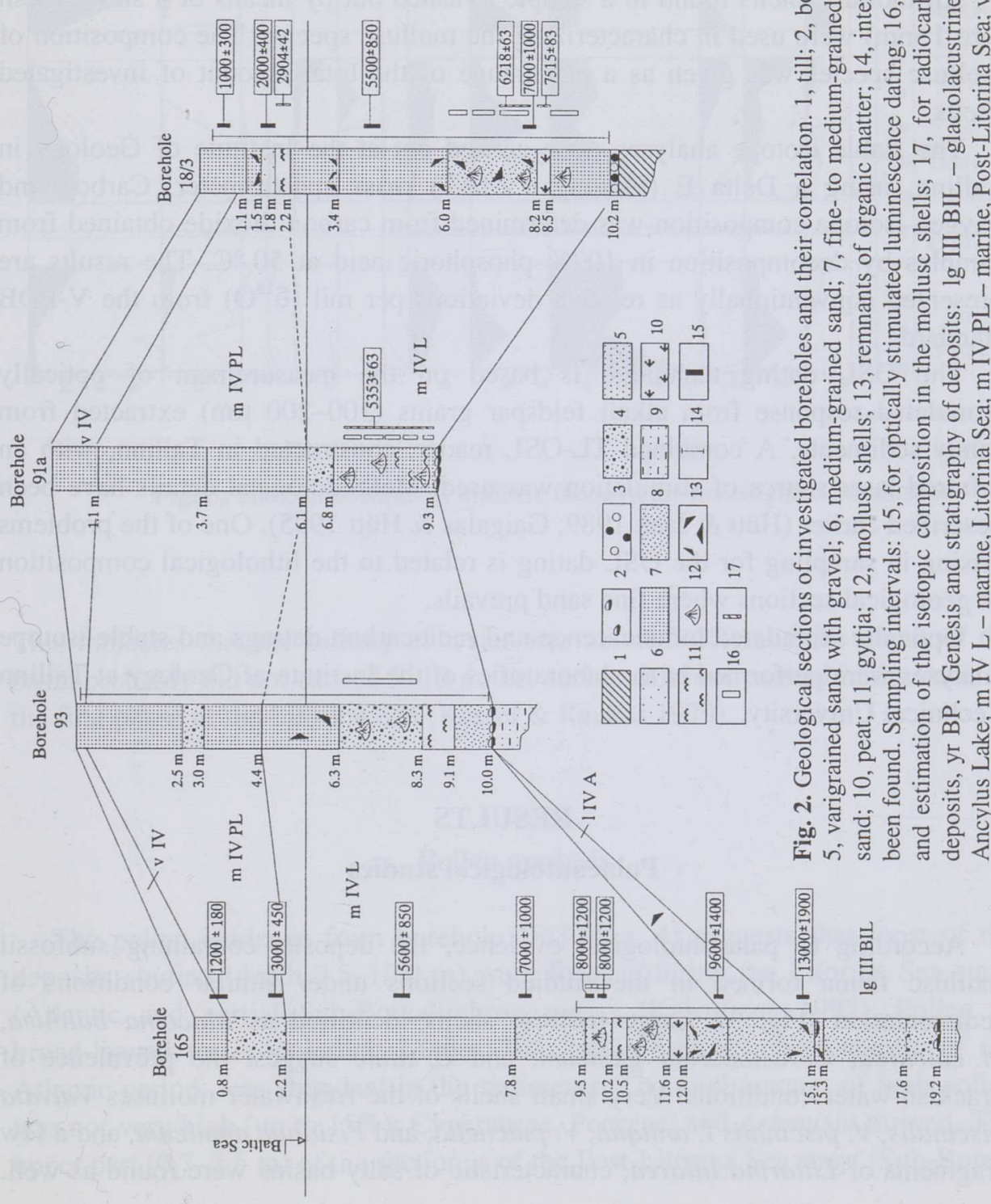

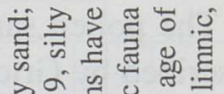

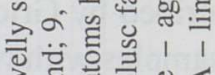

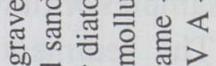

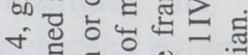

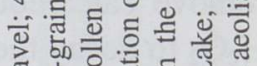

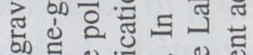
का

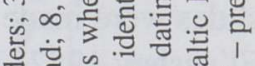

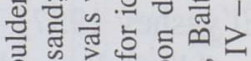

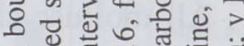
त. 要过 -

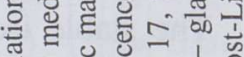
o 0 .

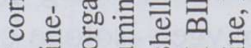

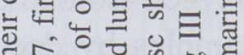

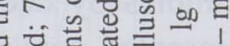
政

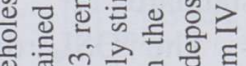
of

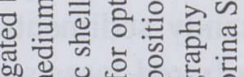
管

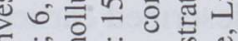

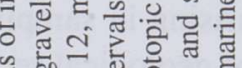

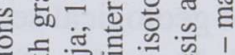

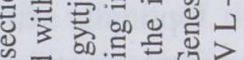

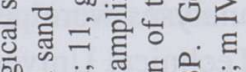

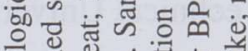

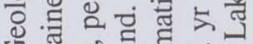

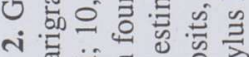
oi 
The pollen samples were prepared in accordance with the standard methods described by Grichyuk (1937) and Erdtman (1943). These included the treatment of samples with $\mathrm{NaOH}, \mathrm{HCl}, \mathrm{KJ}, \mathrm{CDJ}$, and acetolysis.

The sediment samples for diatom analysis were treated with $10 \% \mathrm{HCl}$ to remove calcareous matter, washed with distilled water, and treated with $30 \%$ $\mathrm{H}_{2} \mathrm{O}_{2}$ to decay the organic matter. Samples with a high clay content were washed repeatedly by suspending and dispersing the material in distilled water. Diatom slides were made using A. A. El'yashev's mounting medium (Krishtafovich 1949; El'yashev 1957).

All mollusc shells found in a sample (washed out by means of a sieve, mesh size $1 \mathrm{~mm}$ ) were used in characterizing the mollusc species. The composition of mollusc species was given as a percentage of the total amount of investigated shells.

The stable isotope analyses were carried out at the Institute of Geology in Tallinn, using a Delta E (Finningan MAT) mass spectrometer. Carbon and oxygen isotope composition was determined from carbon dioxide obtained from samples by decomposition in $100 \%$ phosphoric acid at $50{ }^{\circ} \mathrm{C}$. The results are presented conventionally as relative deviations per mil $\left(\delta^{18} \mathrm{O}\right)$ from the V-PDB standard.

The OSL dating technique is based on the measurement of optically stimulated response from alkali feldspar grains (100-200 $\mu \mathrm{m})$ extracted from sandy sediments. A combined TL-OSL reader, constructed in Tallinn, with an infrared laser source of stimulation was used. Methodological details have been described earlier (Hütt \& Jaek 1989; Gaigalas \& Hütt 1995). One of the problems arising in sampling for the OSL dating is related to the lithological composition of geological sections where fine sand prevails.

Optically stimulated luminescence and radiocarbon datings and stable isotope analyses were performed in the laboratories of the Institute of Geology at Tallinn Technical University.

\section{RESULTS}

\section{Palaeontological studies}

According to palaeontological evidence, the deposits containing subfossil mollusc fauna formed in the studied sections under similar conditions of sedimentation (Fig. 3). Large mollusc shells identified as Macoma balthica, M. calcarea, Cerastoderma glaucum, and C. edule suggest the prevalence of brackish-water conditions. Very small shells of the freshwater molluscs Valvata piscinalis, V. piscinalis f. antiqua, V. pulchella, and Pisidium amnicum, and a few fragments of Littorina littorea, characteristic of salty basins were found as well. 


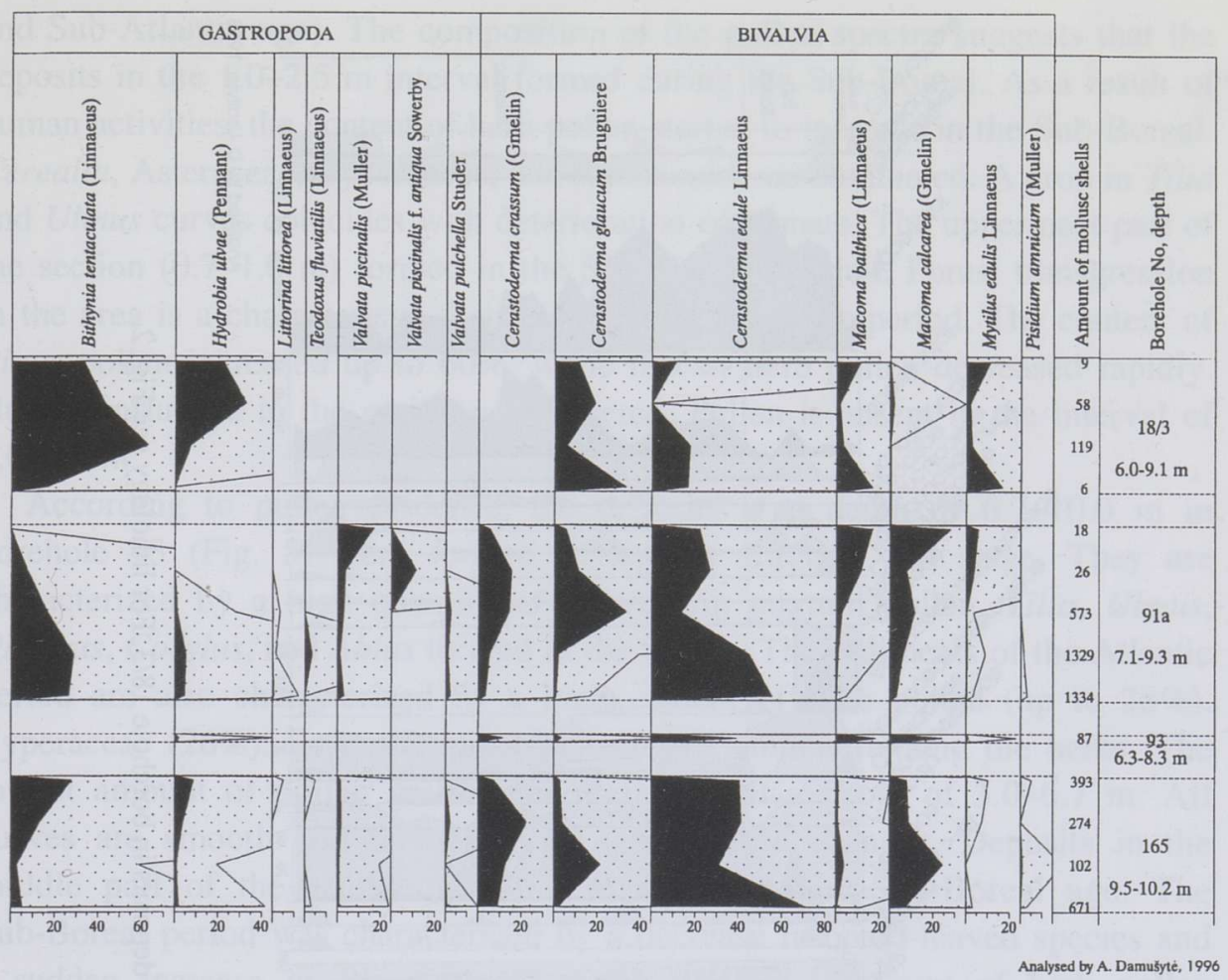

Fig. 3. The composition of mollusc fauna in the investigated boreholes.

This indicates that the salinity of water was about $5-8 \%$ and the depth of the basin probably did not exceed 5-10 m, i.e. such conditions existed in the basin of the first phase of the Litorina Sea (Kessel \& Raukas 1979).

\section{Pollen analysis}

The pollen evidence from borehole 18/3 (Fig. 4) suggests that most of the deposits studied (depth $2.5-10.0 \mathrm{~m}$ ) were formed during the Litorina Sea stage (Atlantic and partial Sub-Boreal chronozones) (Kabailienè 1997). Pollen of broad-leaved trees, including Ulmus, Tilia, and Quercus, characteristic of the Atlantic period, was abundant in the sediments. The total amount of herb pollen was not very high (up to $15 \%$ ); Cyperaceae, Poaceae, and Artemisia thrived. The upper part (0.7-2.5 m) of the section is of the Post-Litorina Sea stage (Sub-Boreal 


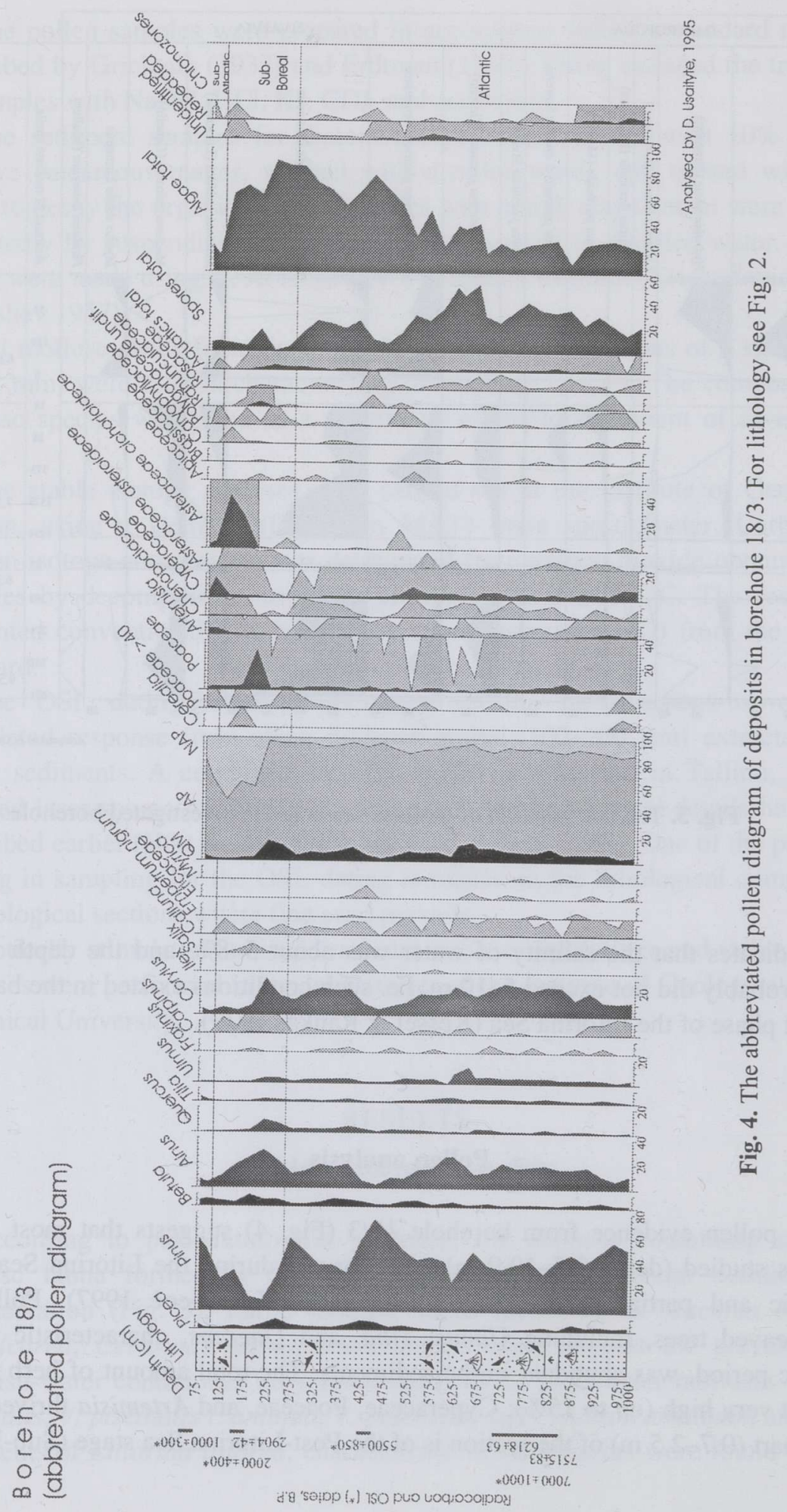


and Sub-Atlantic age). The composition of the pollen spectra suggests that the deposits in the 1.0-2.5 m interval formed during the Sub-Boreal. As a result of human activities, the content of herb pollen started to increase in the Sub-Boreal. Cerealia, Asteraceae, Cyperaceae, and Ranunculaceae dominated. A drop in Tilia and Ulmus curves coincides with deterioration of climate. The uppermost part of the section $(0.7-1.0 \mathrm{~m})$ formed in the Sub-Atlantic period. Forest transgression in the area is a characteristic feature of the Sub-Atlantic period. The content of Pinus pollen increased up to $60 \%$, while that of herb pollen decreased rapidly. Human influence in the region was lowered. Pollen is absent in the interval of 0.0-0.7 m.

According to pollen evidence, the deposits at a depth of $6.7-10.0 \mathrm{~m}$ in borehole 93 (Fig. 5) were formed during the Litorina Sea stage. They are characterized by a high quantity of Quercetum mixtum pollen. Tilia, Ulmus, Quercus, Corylus, and Alnus thrived in the region. The sediments of the Atlantic period are also characterized by a high content of herb pollen (up to 28\%). Cyperaceae (26\%), Poaceae, and Artemisia predominate among the herbs. The lowest amount of pollen grains was registered at a depth of 3.0-6.7 m. All curves are smooth and do not show considerable changes. Deposits in the middle part of the section $(3.0-6.7 \mathrm{~m})$ might be of Sub-Boreal age. The Sub-Boreal period was characterized by a decrease in broad-leaved species and a sudden increase in Pinus (up to 80\%). The total amount of herb pollen decreased. Cyperaceae (6-7\%), Poaceae (9\%), and Caryophyllaceae prevailed among herbs. Tilia (2\%), Corylus, and Calluna are characteristic of the SubAtlantic chronozone. Hence, the upper part $(0.2-3.0 \mathrm{~m})$ of the section was formed in the Sub-Atlantic period.

The situation in borehole 165 (Fig. 6) is more complicated. Pollen was found only between 9.3 and $14.9 \mathrm{~m}$. The lower part of the interval (14.5-14.9 m), with a high content of Cyperaceae, Poaceae, Plantaginaceae, and Filipendula pollen, was formed during the Younger Dryas (11 900-12 $300 \mathrm{yr}$ BP), i.e. at the beginning of the Baltic Ice Lake. Betula makes up $16 \%$ and Pinus reaches $84 \%$, being the dominant species at this depth. Tree pollen clearly prevails over the herbs, shrubs, and dwarf shrubs also in the interval of 13.1-14.5 $\mathrm{m}$. The pollen spectra we have in this interval characterize the beginning of the Holocene. Consequently, the sediments were formed in the Ancylus Lake during the Pre-Boreal-Boreal (8000-9300 yr BP). Quercetum mixtum and Corylus increase in the upper part of the interval (9.3-13.1 m), evidencing the formation of the deposits during the Holocene climatic optimum. Also, the lithological sequence of the deposits in the section and the content of mollusc fauna (Fig. 3) indicate sedimentation in the Litorina Sea (4000-7800 yr BP). 


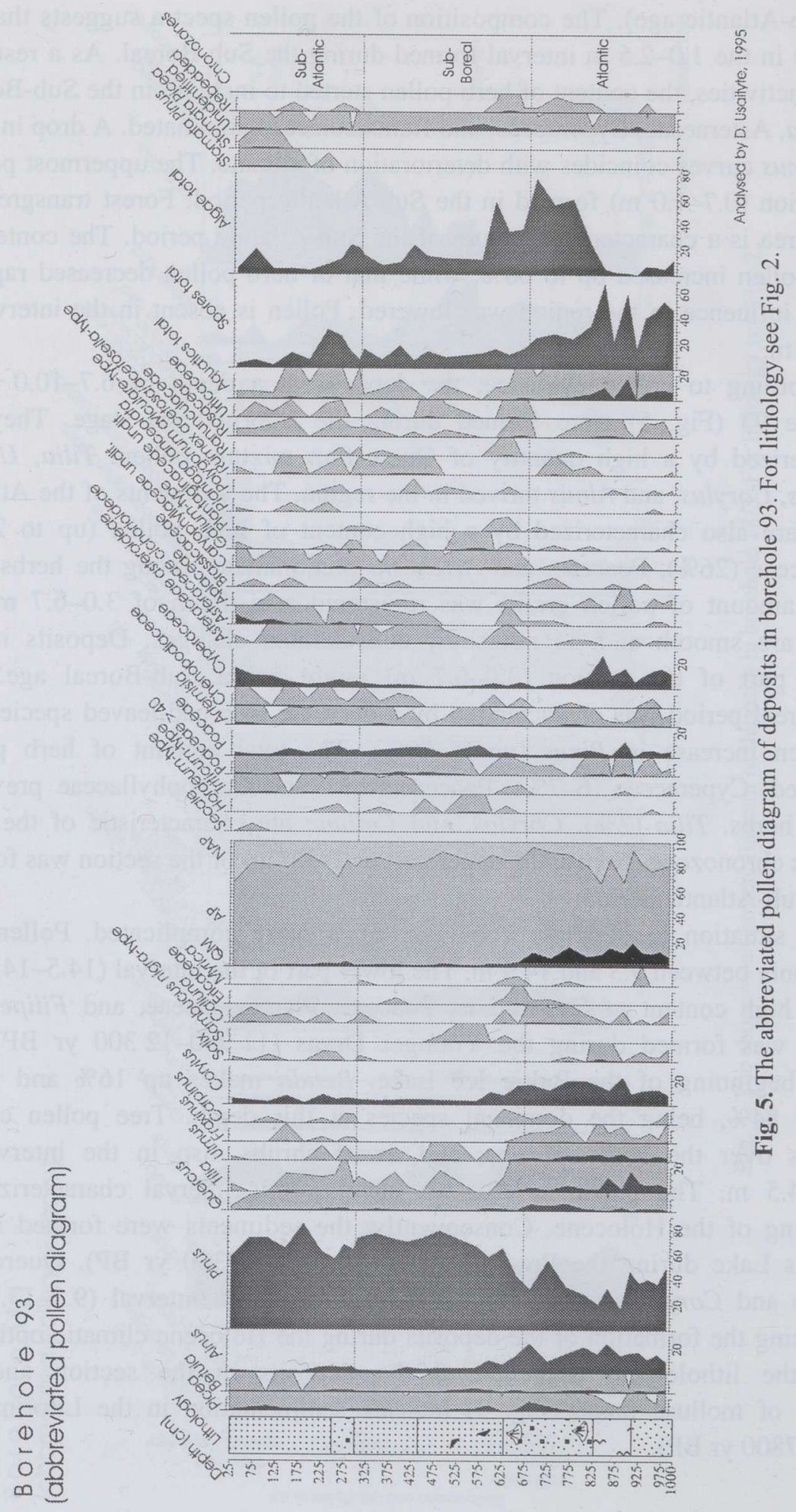




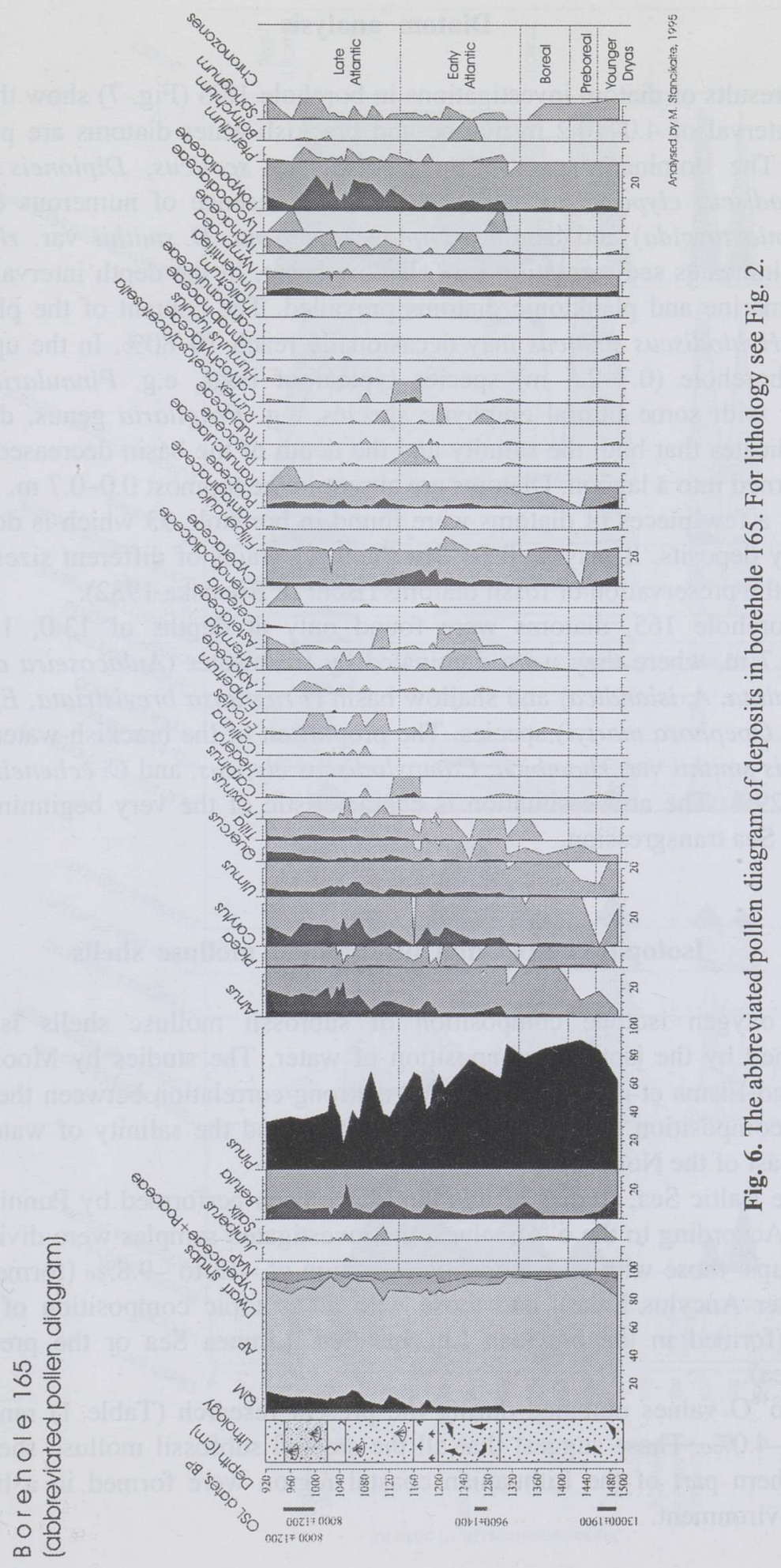




\section{Diatom analysis}

The results of diatom investigations in borehole $18 / 3$ (Fig. 7) show that in the depth interval of 4.0-10.2 m marine and brackish-water diatoms are prevailing (80\%). The dominant species are Hyalodiscus scoticus, Diploneis didyma, Campylodiscus clypeus, and C.echeneis. The presence of numerous epiphytic (Epithemia turgida) and benthic (Diploneis didyma, D. smithii var. rhombica) species indicates sedimentation in a shallow basin. In the depth interval of 2.5$4.0 \mathrm{~m}$, marine and planktonic diatoms prevailed. The content of the planktonic species Hyalodiscus scoticus may occasionally reach 70-80\%. In the upper part of the borehole $(0.7-2.5 \mathrm{~m})$ species typical of bogs, e.g. Pinnularia gibba, together with some littoral epiphytic species, e.g. Fragilaria genus, dominate. This indicates that both the salinity and the depth of the basin decreased and the basin turned into a lagoon. Diatoms are absent in the topmost $0.0-0.7 \mathrm{~m}$.

Only a few pieces of diatoms were found in borehole 93 which is dominated by sandy deposits. It may well be that the sand grains of different sizes did not support the preservation of fossil diatoms (Bohr \& Bilenska 1982).

In borehole 165, diatoms were found only at depths of 13.0, 11.8, and 10.2-10.7 m, where they were dominated by freshwater (Aulacoseira ambiqua, A. granulata, A. islandica) and shallow basin (Fragilaria brevistriata, Epithemia turgida, Opephora martyi) species. The proportion of the brackish-water species Diploneis smithii var. rhombica, Campylodiscus clypeus, and C. echeneis did not exceed $29 \%$. The above situation is characteristic of the very beginning of the Litorina Sea transgression.

\section{Isotopic composition of subfossil mollusc shells}

The oxygen isotope composition of subfossil mollusc shells is mainly determined by the isotopic composition of water. The studies by Mook (1968, 1971) and Eisma et al. (1976) revealed a strong correlation between the oxygen isotope composition of subfossil mollusc shells and the salinity of water at the south coast of the North Sea.

In the Baltic Sea, studies of this kind have been performed by Punning et al. (1988). According to the $\delta^{18} \mathrm{O}$ values, the investigated samples were divided into two groups: those with an isotopic composition of -13 to $-9.8 \%$ (formed in the freshwater Ancylus Lake), and those with an isotopic composition of -6.8 to $-4.7 \%$ (formed in the brackish Litorina Sea, Limnea Sea or the present-day Baltic Sea).

The $\delta^{18} \mathrm{O}$ values obtained during the present research (Table 1) range from -5.7 to $-4.0 \%$ o. These suggest that all the studied subfossil mollusc shells from the northern part of the Lithuanian coastal region were formed in a brackishwater environment. 


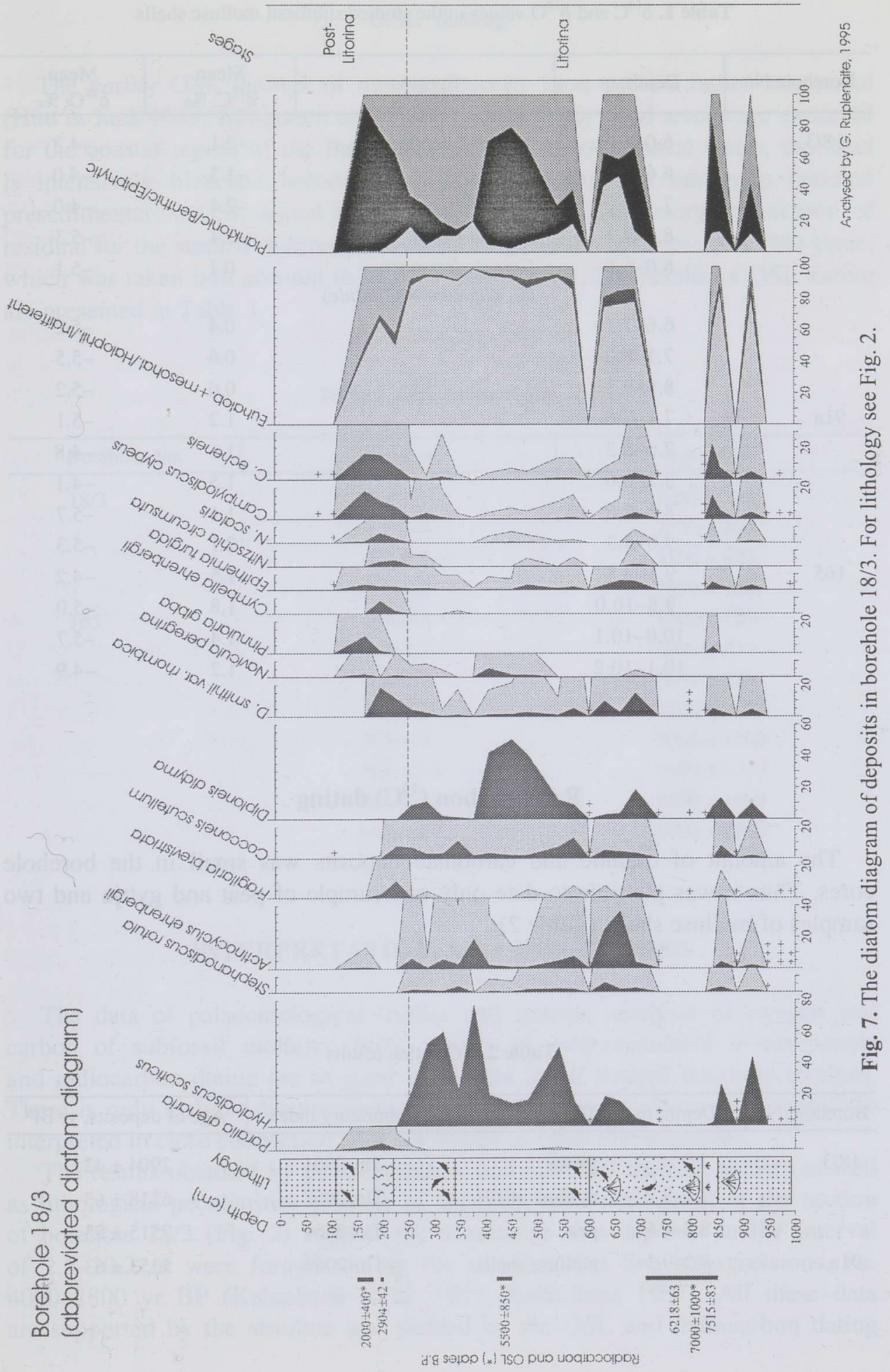


Table 1. $\delta^{13} \mathrm{C}$ and $\delta^{18} \mathrm{O}$ values in the studied subfossil mollusc shells

\begin{tabular}{|c|c|c|c|c|}
\hline Borehole No. & Depth, m & Species & $\begin{array}{c}\text { Mean } \\
\delta^{13} \mathrm{C}, \% o\end{array}$ & $\begin{array}{c}\text { Mean } \\
\delta^{18} \mathrm{O}, \% 0\end{array}$ \\
\hline \multirow[t]{8}{*}{$18 / 3$} & $6.0-6.6$ & Macoma balthica & -2.1 & -4.3 \\
\hline & $6.6-7.1$ & & -1.5 & -4.0 \\
\hline & $7.1-8.0$ & & -2.4 & -4.0 \\
\hline & $8.5-9.1$ & Mytilus edulis & -1.4 & -5.3 \\
\hline & $6.0-6.6$ & $\begin{array}{l}\text { Cerastoderma sp. } \\
(\text { C. glaucum }+ \text { C. edule })\end{array}$ & 0.1 & -5.1 \\
\hline & $6.6-7.1$ & & 0.4 & -5.2 \\
\hline & $7.1-8.0$ & & 0.6 & -5.5 \\
\hline & $8.5-9.1$ & & 0.0 & -5.2 \\
\hline \multirow[t]{5}{*}{$91 \mathrm{a}$} & $7.1-7.6$ & & 1.2 & -5.1 \\
\hline & $7.6-8.2$ & & 1.6 & -4.8 \\
\hline & $8.2-8.6$ & & 1.5 & -4.1 \\
\hline & $8.6-9.0$ & & 1.1 & -5.7 \\
\hline & $9.0-9.3$ & & 2.1 & -5.3 \\
\hline \multirow[t]{4}{*}{165} & $9.5-9.8$ & 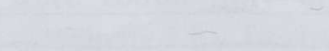 & 1.5 & -4.2 \\
\hline & $9.8-10.0$ & & 1.8 & -5.0 \\
\hline & $10.0-10.1$ & & 1.4 & -5.7 \\
\hline & $10.1-10.2$ & & 1.2 & -4.9 \\
\hline
\end{tabular}

\section{Radiocarbon $\left({ }^{14} \mathrm{C}\right)$ dating}

The amount of organic and carbonate deposits was small in the borehole cores. Thus it was possible to date only one sample of peat and gyttja and two samples of mollusc shells (Table 2).

Table 2. ${ }^{14} \mathrm{C}$ dating results

\begin{tabular}{l|l|l|c|c}
\hline Borehole No. & Depth, $\mathrm{m}$ & Object of dating & Laboratory index & Age of deposits, yr BP \\
\hline \multirow{2}{*}{$18 / 3$} & 2.0 & gyttja & Tln-2061 & $2904 \pm 42$ \\
& $7.1-8.2$ & mollusc shells & Tln-2067 & $6218 \pm 63$ \\
& $8.2-8.5$ & peat & Tln-2064 & $7515 \pm 83$ \\
91a & $8.2-9.3$ & mollusc shells & Tln-2069 & $5353 \pm 63$
\end{tabular}




\section{OSL dating}

The earlier OSL datings of marine deposits have proved rather successful (Hütt \& Jaek 1989; Königsson et al. 1995). Particularly good results are expected for the coastal region of the Baltic Sea. In the shallow coastal water, the sand is intensively bleached before sedimentation, hence, the minimum residual presedimentation OSL signal is practically reached. Laboratory stimulation of residual for the studied sediments was equivalent to the ages less than 300 years, which was taken into account in the age calculations. The results of OSL dating are presented in Table 3.

Table 3. OSL dating results

\begin{tabular}{l|c|c}
\hline Borehole No. & Depth, $\mathrm{m}$ & Age, yr BP \\
\hline $18 / 3$ & $0.4-0.7$ & $1000 \pm 300$ \\
& $1.5-1.8$ & $2000 \pm 400$ \\
& $4.2-4.5$ & $5500 \pm 850$ \\
& $7.9-8.2$ & $7000 \pm 1000$ \\
165 & $0.4-0.8$ & $1200 \pm 180$ \\
& $1.8-2.1$ & $3000 \pm 450$ \\
& $4.7-5.1$ & $5600 \pm 850$ \\
$8.0-8.3$ & $7000 \pm 1000$ \\
& $9.5-9.8$ & $8000 \pm 1200$ \\
& $9.8-10.0$ & $8000 \pm 1200$ \\
& $12.6-12.8$ & $9600 \pm 1400$
\end{tabular}

\section{INTERPRETATION AND DISCUSSIONS}

The data of palaeontological studies and isotopic analysis of oxygen and carbon of subfossil mollusc shells, results of palaeobotanical investigations and radiocarbon dating are in good agreement in all studied borehole sections. There is only a slight disagreement with OSL datings, so these data should be interpreted in close connection with the results of other investigations.

The results obtained by palaeobotanical and subfossil mollusc studies as well as lithological peculiarities (change of deposits: sand-peat-sand) of the section of borehole $18 / 3$ (Fig. 2) support the conclusion that deposits in the interval of $2.5-10.2 \mathrm{~m}$ were formed during the two Litorina Sea transgressions, i.e. 4000-7800 yr BP (Kabailienè et al. 1995; Kabailiené 1997). All these data are supported by the absolute age yielded by the OSL and radiocarbon dating 
(Tables 2, 3). The interval of $0.7-2.5 \mathrm{~m}$ is somewhat more problematic. There is one OSL date ( $2000 \pm 400 \mathrm{yr}$ BP, i.e. the Sub-Atlantic period) from a depth of $1.5-1.8 \mathrm{~m}$ which conflicts with the stratigraphic subdivision based on the results of pollen analysis (depth 1.0-2.5 m, the Sub-Boreal period). Comparison of this date with the radiocarbon age ( $2904 \pm 42 \mathrm{yr} \mathrm{BP}$ ) from a depth of $2.0 \mathrm{~m}$ suggests a changing accumulation rate or even a hiatus between the gyttja (1.8-2.2 $\mathrm{m})$ and the overlying deposits. In view of this and absolute ages, the uppermost part of the deposits $(0.7-2.2 \mathrm{~m})$ probably formed during Post-Litorina Sea stage (less than $4000 \mathrm{yr} \mathrm{BP})$. The formation of the topmost $0.0-0.7 \mathrm{~m}$ was due to recent aeolian processes.

In borehole 93 the subfossil mollusc fauna, characteristic of the Litorina Sea, was found at a depth of 6.3-8.3 m (Fig. 2). According to the results of pollen analysis this interval belongs to the Atlantic and the beginning of the Sub-Boreal chronozones, e.g. the deposits formed during the Litorina Sea stage. The uppermost part of the section, approximately from a depth of $4.4 \mathrm{~m}$ (lithological boundary), was formed during the Post-Litorina Sea stage as confirmed by both the subfossil mollusc studies and radiocarbon dating of mollusc shells $(5353 \pm 63$ yr BP). Lithologically very similar Litorina Sea deposits occur in borehole $91 \mathrm{a}$ in the neighbourhood.

The lower part of the borehole 165 section was stratigraphically subdivided according to data of palaeobotanical investigations. The only OSL date of $13000 \pm 1900 \mathrm{yr} \mathrm{BP}$ is too approximate to allow any correction to the age of the deposits. The deposits occurring above $13.0 \mathrm{~m}$ are a bit older, $9600 \pm 1400 \mathrm{yr}$ BP by the OSL dates. According to the OSL ages, which underlie the stratigraphic subdivision of the topmost part of borehole 165 (to a depth of $9.3 \mathrm{~m}$ ), the deposits occurring at a depth of 2.2-9.3 m were formed in the Litorina Sea, those at a depth of $0.8-2.2 \mathrm{~m}$ in the Post-Litorina Sea, and at a depth of $0.0-0.8 \mathrm{~m}$ as a result of recent aeolian processes. This subdivision confirms the conception about the formation of the Kuršių Nerija Spit (Kabailienè 1990).

The results obtained suggest that the coastal deposits in the northern part of the Lithuanian coastal region were mostly formed during the following Baltic Sea stages: Baltic Ice Lake, Litorina Sea, and Post-Litorina Sea. The Ancylus sediments were identified in a limited area in the northern part of the Kuršiu Nerija Spit only. The detailed stratigraphic subdivision of the borehole sections studied furnishes a good basis for reliable correlation of Late Weichselian and Holocene deposits (Fig. 2).

\section{CONCLUSIONS}

The geological research in the Lithuanian coastal region was aimed at elaborating a detailed stratigraphic subdivision and correlation of Late-Glacial and Holocene deposits and reliable reconstruction of palaeogeographical 
sedimentation conditions in this area. An application of a set of different study methods supported these investigations. The results show that the coastal deposits in the northern part of the Lithuanian coastal region were formed during the Baltic Ice Lake, Ancylus Lake, Litorina Sea, and Post-Litorina Sea stages of the Baltic Sea. The set of the methods used seems representative enough and will be used in the future in studying the deposits which have accumulated under similar geological conditions.

The OSL technique, which was used for the first time in dating of relatively young marine deposits in Lithuania, has yielded the results generally fitting with palaeobotanical, palaeontological, and radiocarbon data, particularly in the case of the deposits younger than 5000 years. More representative results are expected in a few years when the investigations of this kind will be completed in the southern part of the Lithuanian coastal region.

\section{ACKNOWLEDGEMENTS}

The authors wish to thank Meilute Kabailienè for critical reading of the manuscript and Regina Petrauskiene for her kind help with the drawings. We are also grateful to Raivo Rajamäe for radiocarbon data and Helle Kukk for revising the English language of the manuscript. Financial support of the Estonian Science Foundation to Galina Hütt (grant No. 2720) and Rein Vaikmäe (grant No. 2186) is highly appreciated.

\section{REFERENCES}

Bohr, R. \& Bilenska, B. 1982. Conditions of endurance of subfossil diatoms in superficial bottom deposits of the Gulf of Gdansk. Baltica, 7, 51-55.

Eisma, D., Mook, W. G. \& Das, H. A. 1976. Shell characteristics, isotopic composition and trace element contents of some euryhaline molluscs as indicators of salinity. Palaeogeogr. Palaeoclimatol. Palaeoecol., 19, 39-62.

El'yashev, A. A. 1957. About a simple way for preparation of higher solution conditions for diatom analysis. $\operatorname{Tr}$. NIIGRI, 4, 74-75 (in Russian).

Erdtman, G. 1943. An introduction to pollen analysis. Chronica Botanica (Waltham, Mass).

Gaigalas, A. \& Hütt, G. 1995. OSL dating of the Merkine (Eemian) interglacial in Jonionys and the Nemunas glaciation (Rokai section) in Lithuania. PACT, 50, 59-69.

Grichyuk, V. P. 1937. The new method of the sediments treatment for the pollen analysis. Tr. Sov. sektsii AURNE, 3, 159-165 (in Russian).

Gudelis, V. 1955. The main stages of the geological development of the Lithuanian coast in Late- and Post-Glacial times. Sci. Rep. Biol. Geol. Geogr., Vilnius Univ., III, 120-133 (in Lithuanian).

Gudelis, V. 1979. The Quaternary history of the Baltic. Lithuania. In The Quaternary History of the Baltic (Gudelis, V. \& Königsson, L.-K., eds.). Acta Univ. Upsaliensis, Annum Quingentesimum Celebrantis, 1, 159-173. 
Gudelis, V. \& Klimavičienè, V. 1982. On the glacier recession, development of local glacial lakes and the Baltic Ice Lake in the northern part of the Lithuanian seacoast. Baltica, 7, 83-94.

Hütt, G. \& Jaek, I. 1989. Infrared stimulated photoluminescence dating of sediments. Ancient TL, 7, $48-51$.

Kabailiene, M. 1990. Holocene of Lithuania. Mokslas, Vilnius (in Lithuanian).

Kabailiené, M. 1997. Shore line displacement, palaeoecological conditions and human impact in the south-eastern coast of Baltic Sea. In Fifth Marine Geological Conference The Baltic: Abstracts, Excursion Guide (Grigelis, A., ed.), pp. 114-122. Geol. inst., Vilnius.

Kabailienè, M., Savukynienè, N., Stančikaité, M., Ūsaitytè, D. \& Ruplènaitė, G. 1995. Stratigraphy and paleogeography conditions in the environs of Šventoji during Neolithic time according to pollen and diatom data. In Natural Environment, Man and Cultural History on the Coastal Areas of Lithuania: Excursion Guidebook (Kabailiene, M., ed.), pp. 23-25. Mokslas, Vilnius.

Kessel, H. \& Raukas, A. 1979. The Quaternary history of the Baltic. Estonia. In The Quaternary History of the Baltic (Gudelis, V. \& Königsson, L.-K., eds.). Acta Univ. Upsaliensis, Annum Quingentesimum Celebrantis, 1, 127-146.

Königsson, L.-K., Possnert, G. \& Hütt, G. 1995. Early Baltic sea level history based on AMSdating of small mollusc shells. J. Coastal Res. Spec. Issue, 17, 923-926.

Krishtafovich, A. N. (ed.). 1949. Diatomovyi analiz, 1. Gosgeolizdat, Moscow (in Russian).

Mikalauskas, A. P. \& Lukoševičius, L. S. 1987. About structure and age of the ancient beach ridge of the NW Baltic coast of the Lithuanian SSR. In Geologicheskoe stroenie chetvertichnykh otlozhenij na dne Baltijskogo morya $i$ zakonomernosti rasprostraneniya poleznykh iskopaemykh (Kabailienè, M., ed.), pp. 53-55. Vilnius (in Russian).

Mikalauskas, A. P., Mikutiené, L. J., Beconis, M. I. \& Gentvilas, E. S. 1986. Degradation of the glacier and drainage of meltwater on the territory of West Lithuania. In Issledovanie lednikovykh obrazovanij Pribaltiki (Kondratiene, O. P. \& Mikalauskas, A. P., eds.), pp. 114-118. Vilnius (in Russian).

Mook, W. G. 1968. Isotopic equilibrium between shells and their environment. Science, 159, 874-875.

Mook, W. G. 1971. Palaeotemperatures and chlorinities from stable carbon and oxygen isotopes in shell carbonate. Palaeogeogr. Palaeoclimatol. Palaeoecol., 9, 245-263.

Punning, J.-M., Martma, T., Kessel, H. \& Vaikmäe, R. 1988. The isotopic composition of oxygen and carbon in the subfossil mollusc shells of the Baltic Sea as indicator of palaeosalinity. Boreas, 17, 27-31.

\title{
LEEDU RANNIKUPIIRKONNA HILIS-VALDAI JA HOLOTSEENI SETETE STRATIGRAAFILINE KORRELATSIOON
}

\author{
Albertas BITINAS, Aldona DAMUŠYTĖ, Galina HÜTT, Tõnu MARTMA, \\ Giedre RUPLĖNAITÉ, Miglè STANČIKAITĖ, Daiva ŪSAITYTÉ \\ ja Rein VAIKMÄE
}

Leedu rannikupiirkond on võtmeala mitmesuguste Läänemere arengut hilisValdais ja holotseenis mõjutanud kvaternaarigeoloogia probleemide lahendamisel. Siinne kirjutis käsitleb hilis-Valdai ja holotseeni setteid kolmes kohas Leedu rannikupiirkonna põhjaosas. On kasutatud palünoloogilist ja diatomeeanalüüsi, subfossiilsete molluskite fauna paleontoloogilist uurimist, molluski- 
kodade isotoopanalüüsi $\left(\delta^{18} \mathrm{O}, \delta^{13} \mathrm{C}\right)$, molluskite ja orgaaniliste setete dateerimist radiosüsiniku meetodil ja liivsetete dateerimist optiliselt stimuleeritud luminestsentsi (OSL) meetodil. Uuringud näitasid, et Leedu rannikupiirkonna põhjaosa setted moodustusid Läänemere arengu Balti jääpaisjärve, Antsülusjärve, Litoriinamere ja viimase järgses staadiumis.

OSL meetod, mida kasutati esmakordselt suhteliselt noorte mereliste setete dateerimiseks Leedus, andis tulemusi, mis langesid hästi kokku paleobotaanilise, paleontoloogilise ja radiosüsiniku analüüsi tulemustega, eriti 5000 aastast nooremate setete puhul.

\section{СТРАТИГРАФИЧЕСКАЯ КОРРЕЛЯЦИЯ ПОЗДНЕВАЛДАЙСКИХ И ГОЛОЦЕНОВЫХ ОТЛОЖЕНИЙ ЛИТОВСКОГО ПОБЕРЕЖЬЯ}

Альбертас БИТИНАС, Алдона ДАМУШИТЕ, Галина ХЮТТ, ТЫнУ МАРТМА, Гедре РУПЛЕНАЙТЕ, Мигле СТАНЧИКАЙТЕ, Дайва УСАЙТИТЕ и Рейн ВАЙКМЯЕ

Прибрежный регион Литвы является ключевым при решении различных проблем четвертичной геологии, в частности тех, которые касаются развития Балтийского моря в поздневалдайское и голоценовое время. Образцы отложений этого возраста были отобраны из трех местоположений на северном побережье Литвы и подвергнуты комплексному изучению: проведены палинологический и диатомовый анализы, палеонтологические исследования, изотопный анализ $\left(\delta^{13} \mathrm{C}\right.$ и $\left.\delta^{18} \mathrm{O}\right)$ раковин моллюсков, радиоуглеродное датирование раковин и органики, а также оптически стимулированная люминесценция (ОСЛ) при датировании песчаных отложений. Основные результаты датирования свидетельствуют о том, что береговые отложения в этом регионе Литвы формировались на протяжении всех стадий развития Балтийского моря: Балтийского ледникового озера, Анцилового озера, Литоринового моря и пост-литоринового времени.

Результаты впервые использованной ОСЛ методики датирования для определения возраста относительно молодых морских песчаных отложений Литвы хорошо коррелируют с данными других рутинных методов исследования. 